\title{
PEMBERDAYAAN IBU RUMAH TANGGA DALAM PENERAPAN PHBS CUCI TANGAN PAKAI SABUN DI AIR MENGALIR PADA ANAK USIA 6 - 10 TAHUN
}

\author{
Untung Halajur ${ }^{1}$ \\ ${ }^{1}$ Jurusan Keperawatan, Poltekkes Kemenkes Palangka Raya, Indonesia \\ *email: untunghalajur@yahoo.com
}

\begin{abstract}
Community empowerment is a process to foster awareness and ability of the community to maintain and improve welfare in the family. One way is to implement clean and healthy living behaviors (PHBS) in the household setting. One indicator used is washing hands with running water and using soap. Hand washing with soap is one of sanitation measures by cleaning hands and fingers and nails using running water and soap and breaking the chain of microorganisms as a source of disease; such as trachoma and eye pain (red eye) and pathogenic germs that are the main causes of ARI (Upper Respiratory Infection) are very common in the fingers and palms. Cultivating hand washing using soap properly, is expected to reduce mortality and morbidity due to diseases related to water, sanitation and clean and healthy living behaviors. 3 The purpose of this community service activity is to increase family knowledge and understanding of the importance of hand washing in four important time to prevent transmission of disease through the hands. The targets in this activity are children aged 6-10 years and housewives who are not working and aged $<45$ years by visiting homes and providing health education and training in the form of CPTS skills training with seven steps. Then for 21 days a home visit was conducted to assist and evaluate the behavior of CPTS.
\end{abstract}

Keywords: Hand washing, PHBS

\begin{abstract}
ABSTRAK
Pemberdayaan masyarakat adalah proses untuk menumbuhkan kesadaran dan kemampuan masyarakat dalam memelihara dan meningkatkan kesejahteraan dalam keluarga. Salah satunya adalah dengan melakukan penerapan perilaku hidup bersih dan sehat (PHBS) di tatanan rumah tangga. Salah satu indikator yang dipakai adalah kegiatan mencuci tangan dengan air mengalir dan menggunakan sabun. Mencuci tangan dengan sabun adalah salah satu tindakan sanitasi (kebersihan) dengan membersihkan tangan dan jari jemari serta kuku-kuku menggunakan air mengalir dan sabun dan memutuskan mata rantai mikroorganisme sebagai sumber penyakit; seperti trachoma dan sakit mata (mata merah) serta kuman patogen yang menjadi penyebab utama ISPA (Infeksi Saluran Pernafasan Atas) sangat umum dijumpai pada jari dan telapak tangan. Membudayakan cuci tangan menggunakan sabun secara benar, diharapkan dapat menurunkan angka kematian dan kesakitan akibat penyakit-penyakit yang berkaitan dengan air, sanitasi serta perilaku hidup bersih dan sehat. ${ }^{3}$ Tujuan kegiatan pengabdian masyarakat ini untuk meningkatkan pengetahuan dan pembahaman keluarga tentang pentingnya cuci tangan di empat waktu penting

17 | Edukasi Masyarakat Sehat Sejahtera (EMaSS) : Jurnal Pengabdian kepada Masyarakat Volume 2 No.1 Tahun 2020
\end{abstract}


untuk mencegah penularan penyakit melalui tangan. Sasaran dalam kegiatan ini adalah anak usia 6 - 10 tahun dan ibu rumah tangga yang tidak bekerja dan berusia $<45$ tahun dengan melakukan kunjungan rumah dan memberikan pendidikan dan pelatihan kesehatan berupa pelatihan keterampilan CPTS dengan tujuh langkah. Kemudian selama 21 hari dilakukan kunjungan rumah untuk melakukan pendampingan dan evaluasi perilaku CPTS.

Kata kunci : Cuci tangan, PHBS

\section{PENDAHULUAN}

Pemberdayaan masyarakat ialah upaya atau proses untuk menumbuhkan kesadaran, kemauan, dan kemampuan masyarakat dalam mengenali, mengatasi, memelihara, melindungi dan meningkatkan kesejahteraan mereka sendiri, salah satu bagian dari masyarakat adalah keluarga (Maulana, 2018). Keluarga sebagai unit terkecil dari masyarakat, terdiri atas kepala keluarga dan beberapa orang yang berkumpul dan tinggal disuatu tempat dibawah suatu atap dalam keadaan saling ketergantungan (Soekadji, 2013). Tingkat kesehatan individu berkaitan dengan tingkat kesehatan keluarga, begitu juga sebaliknya dan tingkat fungsional keluarga sebagai unit terkecil dari komunitas dapat mempengaruhi derajat kesehatan sistem diatasnya.

Salah satu kegiatan yang dapat dilakukan untuk meningkatkan derajat kesehatan keluarga adalah dengan melakukan penerapan perilaku hidup bersih dan sehat (PHBS) di tatanan rumah tangga. PHBS di tatanan rumah tangga merupakan sekumpulan perilaku yang dipraktikan oleh anak dan semua anggota keluarga yang ada dirumah tangga atas dasar kesadaran sebagai hasil pembelajaran, sehingga secara mandiri mampu mencegah penyakit, meningkatkan kesehatannya, salah satu indikator yang dipakai sebagai ukuran untuk menilai PHBS di tatanan rumah tangga adalah kegiatan mencuci tangan dengan air mengalir dan menggunakan sabun.

Mencuci tangan dengan sabun adalah salah satu tindakan sanitasi (kebersihan) dengan membersihkan tangan dan jari jemari serta kuku-kuku menggunakan air mengalir dan sabun dan memutuskan mata rantai mikroorganisme sebagai sumber penyakit; seperti trachoma dan sakit mata (mata merah) serta kuman patogen yang menjadi penyebab utama ISPA (Infeksi Saluran Pernafasan Atas) sangat umum dijumpai pada jari dan telapak tangan. Membudayakan cuci tangan menggunakan sabun secara benar, diharapkan dapat menurunkan angka kematian dan kesakitan akibat penyakit-penyakit yang berkaitan dengan air, sanitasi serta perilaku hidup bersih dan sehat (Sucihati, 2018)

18 | Edukasi Masyarakat Sehat Sejahtera (EMaSS) : Jurnal Pengabdian kepada Masyarakat Volume 2 No.1 Tahun 2020 


\section{METODE}

Pengabdian masyarakat dilakukan dilakukan di 2 keluarga dengan masing-masing 2 orang anak usia 6 - 10 tahun dan 1 ibu rumah tangga yang tidak bekerja dan berusia < 45 tahun sehingga jumlah responden 6 orang. Metode pengabdian berupa kunjungan rumah dan memberikan pendidikan dan pelatihan kesehatan khususnya kepada ibu dan anak, berupa pelatihan keterampilan CPTS dengan tujuh langkah. Kemudian selama 21 hari dilakukan kunjungan rumah untuk melakukan pendampingan dan evaluasi perilaku CPTS.

\section{HASIL DAN PEMBAHASAN}

Berdasarkan hasil kuesioner bahwa $100 \%$ orang tua dapat mengerti dan memahami serta dapat mempraktikan CPTS tersebut, untuk penilaian pada anak dilakukan dengan cara menanyakan kepada anak tentang langkah CPTS, hasil yang didapat sekitar 90\% anak sudah mengerti dan dapat melakukan CPTS. Kegiatan pelatihan ctps pada orangtua dan anak berhasil dilakukan pada setiap tahapannya, sehingga orangtua dan anak dapat menerapkan dan melakukan langsung secara mandiri. Selanjutnya setiap 2 hari sekali akan dilakukan kunjungan rumah oleh mahasiswa untuk melakukan pendampingan dan evaluasi kegiatan CPTS.

Hasil yang didapat selama evaluasi 21 hari tersebut, pada minggu pertama anak masih belum melakukan CPTS pada saat empat penting tersebut, terkadang masih kembali seperti kebiasaan cuci tangan yang sudah biasa dilakukan, pada minggu kedua kegiatan CPTS yang dilakukan anak juga masih belum membudaya disetiap waktu empat penting tersebut walaupun setiap hari sudah dilakukan, pada minggu ketiga anak sudah melakukan perilaku CPTS setiap hari di empat waktu penting tersebut walaupun kadang masih ada hanya ditiga waktu penting. Waktu penting yang sering terlupakan adalah sewaktu makan siang, alasanya karena sudah lapar jadi CPTS yang benar tidak dilakukan karena mau cepat makan.

\section{SIMPULAN}

Orang tua dan anak dapat mengerti dan mampu mendemonstrasikan perilaku cpts. Serta orang tua mampu mendorong anak untuk mau melakukan perilaku cpts di empat saat penting; sebelum makan pagi, makan siang, makan malam dan setelah dar toilet.

19 | Edukasi Masyarakat Sehat Sejahtera (EMaSS) : Jurnal Pengabdian kepada Masyarakat Volume 2 No.1 Tahun 2020 


\section{DAFTAR PUSTAKA}

Maulana.(2018). Promosi Kesehatan.Jakarta:EGC.

Soekadji, S. (2013). Modifikasi Perilaku Penerapan Sehari-hari \& Penerapan Profesional.Yogyakarta:Pratama.

Sucihati. (2018). Pengaruh Strategi Promosi Kesehatan Terhadap Peningkatan PHBS Pada Tatanan Rumah Tangga di Kecamatan Patumbak Kabupaten Deli Serdang.Sekolah Pasaca Sarjana Universitas Sumatera Utara.Medan.Tesis.

20 Edukasi Masyarakat Sehat Sejahtera (EMaSS) : Jurnal Pengabdian kepada Masyarakat Volume 2 No.1 Tahun 2020 